\title{
PENGARUH KONSUMSI TEH DAUN KELOR TERHADAP PENINGKATAN PRODUKSI ASI DI GROBOGAN
}

\author{
Nurulistyawan Tri Purnanto ${ }^{1}$, Laily Himawati ${ }^{2}$, Nur Ajizah ${ }^{3}$ \\ ${ }^{1}$ Prodi Keperawatan Universitas An Nuur \\ ${ }^{2}$ Prodi DIII Kebidanan Universitas An Nuur \\ ${ }^{3}$ Bidan Puskesmas Grobogan Kabupaten Grobogan \\ nurulistyawan.tp@gmail.com
}

\begin{abstract}
ABSTRAK
Rendahnya cakupan ASI eksklusif di Indonesia menjadikan anak terkurangi haknya untuk mendapatkan makanan bernutrisi tinggi bagi pertumbuhan. Hal ini dikarenakan kurangnya produksi ASI pada ibu menyusui. Pemberian tindakan non farmakologi seperti teh daun kelor diharapkan mampu meningkatkan produksi ASI sehingga anak tetap mendapatkan ASI. Penelitian ini bertujuan untuk untuk mengetahui pengaruh konsumsi teh daun kelor terhadap peningkatan produksi ASI di Kabupaten Grobogan. Metode penelitian ini berjenis quasi experimental study dengan menggunakan one group prepost test design pada 60 responden. Intervensi dilakukan selama 3 minggu untuk menilai produksi ASI antara Pre dan Post intervensi. Data dianalisa dengan menggunakan Uji Paired t-Test. Hasil penelitian menunjukkan rata-rata ASI pada tahap pre-test sebanyak 152,00 meningkat menjadi 158,50 pada tahap post-test. Terdapat perbedaan jumlah ASI dengan p-value sebesar 0,002 dengan nilai korelasi sebesar 0,934. Kesimpulan penelitian ini adalah terdapat pengaruh yang signifikan pada konsumsi teh daun kelor untuk produksi ASI.
\end{abstract}

Kata Kunci : Teh Daun Kelor, Produksi ASI

\begin{abstract}
The low coverage of exclusive breastfeeding in Indonesia lead to children less entitled to got exclusive nutritious food for their growth. This is due to the lack of breast milk production. Non-pharmacological treatmen such as Moringa tea is expected to be able to increase breast milk production. The aims of study was to determine the effect of Moringa tea consumption to increasing breast milk production in Grobogan Regency. This research method was using a quasi experimental study using one group prepost test design on 60 respondents. Intervention was carried out for 3 weeks to assess breast milk production between Pre and Post intervention. Data were analysis using Paired t-Test. The results showed that the average of breast milk (pre-test) was 152.00, increasing to 158.50 (post-test). There was a difference in the amount of breast milk with $p$ value of 0.002 and a value of 0.934. The conclusion of this study was a significant effect of Moringa tea consumption to increasing breast milk production.
\end{abstract}

Keyword: Moringa Tea, Breast Milk 


\section{LATAR BELAKANG}

Air Susu Ibu (ASI) adalah cairan hasil sekresi kelenjar payudara ibu yang wajib diberikan kepada bayi sejak dilahirkan sampai usia 6 bulan, tanpa menambahkan dan/atau mengganti dengan makanan atau minuman lain atau sering disebut dengan ASI eksklusif (Kemenkes 2012). WHO juga merekomendasikan bahwa ASI eksklusif wajib diberikan sampai 6 bulan dan setelah itu dilanjutkan dengan MP-ASI (Destyana dkk, 2018). Hal ini dikarenakan banyaknya kandungan zat gizi dan nutrisi yang terkandung dalam ASI sehingga mampu untuk meningkatkan kesehatan anak. Sayangnya, angka pemberian ASI belum sesuai dengan yang ditargetkan.

Data menunjukkan, di Indonesia cakupan pemberian ASI tahun 2015 hanya 30,2\% sedangkan pada tahun 2017 naik menjadi 35\% (Kemenkes RI, 2015; Riskesdas, 2013). Angka tersebut masih jauh di bawah rekomendasi WHO yaitu sebesar 50\% (Indriyani, 2018). Artinya masih banyak bayi usia $0-6$ bulan yang kehilangan haknya untuk mendapatkan ASI sebagai sumber nutrisi bagi pertumbuhannya. Salah satu faktor penyebabnya adalah karena adanya penurunan produksi ASI pada ibu (Destyana dkk, 2018). Penurunan produksi ASI ini dapat disebabkan karena kondisi stres ibu, lelah bekerja, kondisi kesehatan, produksi tidak lancar maupun psikologis ibu sendiri (Bobak et al. 2010). Padahal normalnya ASI akan melimpah produksinya setelah bayi berusia 5 minggu (Monika, 2014).

Beranjak dari permasalahan tersebut, ada banyak cara yang dapat dilakukan untuk memperlancar ASI diantaranya melalui tidnakan non farmakologi seperti konsumsi daun kelor. Kelor merupakan tanaman perdu yang tumbuh diarea pekarangan namun mempunya khasiat sebagai pelancar ASI (Kurniasih, 2013). Ekstrak teh daun kelor merupakan bentuk produksi daun kelor yang lebih mudah untuk diminum, praktis, namun tetap memiliki khasiat tinggi sebagai pelancar produksi ASI. Melalui rutin konsumsi teh daun kelor, diharapkan ibu akan mampu untuk meningkatkan produksi ASI, sehingga secara tidak langsung bayi juga akan terpenuhi nutrisinya. Berdasarkan permasalahan tersebut, maka rumusan masalah penelitian ini adalah adakah pengaruh konsumsi teh daun kelor terhadap peningkatan produksi ASI di Kabupaten Grobogan

\section{METODE PENELITIAN}

Penelitian ini berjenis quasi experimental study dengan menggunakan one group prepost test design (Notoatmodjo, 2010; Arikunto, 2010). Sampel penelitian ini adalah 60 responden yang dipilih menggunakan teknik simple random sampling melalui kriteria inklusi dan eks-klusi (Sugiyono, 2010). Tahap Intervensi dilakukan selama 3 minggu dengan memberikan teh daun kelor kepada responden untuk dikonsumsi. Penelitian ini dinilai dengan membandingkan jumlah produksi ASI antara Pre dan Post intervensi. Data dianalisa dengan menggunakan Uji Paired t-Test (Notoatmodjo, 2010; Arikunto, 2010).

\section{HASIL DAN PEMBAHASAN}

\section{Hasil Penelitian}

Tabel 1 Hasil Analisa Paired t-Test

\begin{tabular}{lccccc}
\hline \multicolumn{1}{c}{ Variabel } & Mean & SD & Cor & t & $\begin{array}{c}\text { Sig. (2- } \\
\text { tailed) }\end{array}$ \\
\hline Jumlah ASI Pre Test - & 152,00 & 15,712 &, 934 & $-3,204$ &, 002 \\
Jumlah ASI Post Test & 158,50 & & & \\
\hline
\end{tabular}


Berdasarkan tabel di atas dapat diketahui bahwa terdapat perbedaan yang tinggi pada jumlah ASI antara sebelum dan setelah pemberian intervensi dengan $p$-value sebesar 0,002 dengan nilai korelasi sebesar 0,934 .

\section{Pembahasan}

Hasil penelitian menunjukkan bahwa produksi ASI pada tahap post test memiliki nilai mean lebih besar besar dari pada tahap pre test yaitu selisih 6,50. Hal ini dapat diartikan bahwa konsumsi daun kelor telah terbukti mampu untuk meningkatkan jumlah produksi ASI pada ibu menyusui. Peningkatan ini juga didukung dengan adanya nilai pvalue sebesar 0,002 dengan tingkat keeratan signifikansi sebesar 0,934 yang berarti memiliki pengaruh yang sangat kuat. Artinya, konsumsi daun kelor secara rutin selama 3 minggu (sesuai dengan intervensi) terbukti mampu meningkatkan produksi ASI pada ibu menyusui.

Ditinjau dari segi teori, daun kelor memang memiliki kandungan senyawa Fitosterol yang berfungsi untuk meningkatkan dan melancarkan produksi ASI (efek laktogogum) (Kurniasih. 2013). Selain Fitoserol, pada daun kelor juga mengandung Fe $5,49 \mathrm{mg} / 100 \mathrm{gr}$ dan juga sitosterol 1,15\%/100gr dan stigmasterol 1,52\%/100gr, dimana zat-zat tersebut mampu untuk merangsang peningkatan produksi ASI (Nurcahyati, 2014). Jadi dengan mengkonsumsi teh daun kelor secara rutin setiap hari berarti secara tidak langsung pada ibu menyusui memiliki senyawa fitosterol yang cukup sehingga berdampak pada peningkatan dan kelancaran ASI selama menyusui (Luthfiyah, 2012).

Selain dari faktor daun kelor, ada ada beberapa faktor lainnya yang dapat mempengaruhi produksi ASI diantaranya adalah kondisi stres ibu, lelah bekerja, kondisi kesehatan, produksi tidak lancar maupun psikologis ibu sendiri (Bobak et al. 2010). Analisa karakteristik hasil penelitian menunjukkan bahwa ibu mayoritas bekerja di rumah sebagai Ibu Rumah Tangga yaitu sebanyak 28 (46,7\%) responden yang artinya tingkat kelelahan ibu selama di rumah juga dapat dikendalikan oleh responden. Ditinjau dari segi kesehatan dan kelancaran ASI, hasil penelitian juga menunjukkan bahwa responden saat ini menyusui pada anak ke-2 (persalinan ke-2) yaitu sebanyak $24(40,0 \%)$ responden dengan frekuensi menyusui perhari lebih dari 8 kali sebanyak $36(60,0 \%)$ responden. Artinya ibu telah berpengalaman dalam menyusui sehingga dimungkinkan payudara telah terbiasa untuk memproduksi ASI untuk kebutuhan menyusui.Disinilah sebenarnya kebutuhan ibu akan bahan baku ASI sangat dibutuhkan, dan salah satu alternatif untuk menambah bahan baku produksi ASI adalah dengan konsumsi teh daun kelor (Nurcahyati, 2014).

\section{Keterbatasan}

Pandemi Covid-19 menjadikan peneliti harus melakukan pengambilan data dari rumah ke rumah disetiap responden dengan tetap mematuhi Protokol Kesehatan. Hal ini menjadikan waktu lebih lama dalam pengumpulan data untuk tetap menjaga kesehatan dan pencegahan penularan Covid-19. Penelitian ini juga tidak mengontrol faktor makanan yang dikonsumsi ibu selama intervensi. Hal ini menjadikan hasil penelitian ini tidak dapat digeneralisasi dengan asumsi hanya dengan mengkonsumsi daun kelor mampu untuk meningkatkan produksi ASI mengingat faktor makanan seperti kacang-kacangan juga mampu meningkatkan produktifitas ASI pada ibu menyusui.

\section{UCAPAN TERIMA KASIH}

1. Direktorat Riset Dan Pengabdian Masyarakat (DRPM) KemristekDIKTI

2. LLDIKTI VI Jawa Tengah 


\section{SIMPULAN DAN SARAN}

\section{Simpulan}

1. Terdapat kenaikan rata-rata produksi ASI antara pre-test dan post yaitu sebesar 152,00 menjadi 158,50 ;

2. Terdapat pengaruh yang signifikan pada produksi ASI setelah intervensi dengan pvalue sebesar 0,002 dan nilai korelasi sebesar 0,934

\section{Saran}

Berdasarkan hasil penelitian menunjukan bahwa konsumsi daun kelor mampu meningkatkan produksi ASI. Oleh karena itu, Ibu diharapkan untuk mampu memanfaatkan daun kelor sebagai sumber bahan peningkat ASI karena murah, mudah didapat, serta mudah ditanam namun memiliki manfaat yang sangat besar. Peneliti selanjutnya juga diharapkan untuk melakukan penelitian yang lebih lanjut melalui experimen study dengan cara mengontrol faktor lain yang mampu meningkatkan produksi ASI seperti pola dan menu yang dimakan ibu mengingat ada banyak faktor yang mampu meningkatkan produksi ASI dari segi makanan yang dikonsumsi Ibu selama menyusui.

\section{DAFTAR PUSTAKA}

Arikunto, Suharsini. (2010). Prosedur Penelitian Suatu Pendekatan Praktek. PT. Rineka Cipta: Jakarta

Bobak, Lowdermilk \& Jensen. (2010). Buku Ajar Keperawatan Maternitas IV. EGC: Jakarta.

Destyana dkk. (2018). Hubungan Peran Keluarga dan Pengetahuan Ibu Terhadap Pemberian ASI di Desa Tanah Merah Kabupaten Tangerang. Indonesian Journal of Human Nutrition. eSSN. 2355-3987

Indriyani Astuti, (2018). Pemberian ASI Eksklusif di Indonesia Hanya 35\%. Media Indonesia. Evailable source https://mediaindonesia.com/read/detail/175814pemberianasi-eksklusif-di-indonesia-hanya-35

Kemenkes. (2012). Peraturan Pemerintah Republik Indonesia No 33 tahun 2012 tentang Pemberian Air Susu Ibu Eksklusif. Kemenkes RI: Jakarta

Kementerian Kesehatan RI. (2015). Profil Kesehatan Indonesia Tahun 2015. Kementerian Kesehatan RI: Jakarta.

Kurniasih. (2013). Khasiat Dan Manfaat Daun Kelor Untuk Penyembuhan Berbagai Penyakit. Pustaka baru Press: Yogyakarta:

Luthfiyah, F. (2012). Potensi Gizi Daun Kelor (Moringa Oleifera). Volume 6. Media Bina Ilmiah: Nusa Tenggara Barat.

Monika, F.B. (2014). Buku Pintar ASI dan Menyusui. Noura Books: Jakarta.

Notoatmodjo, Soekidjo. (2010). Metodologi Penelitian Kesehatan. PT Rineka Cipta: Jakarta.

Nurcahyati, E. (2014). Khasiat Dahsyat Daun Kelor. Jendela Sehat: Jakarta.

Nursalam. (2012). Manajemen Keperawatan : Aplikasi dalam Praktik Keperawatan Profesional (Ed 3). Salemba Medika : Jakarta.

Riskesdas. (2013). Laporan Riset Kesehatan Dasar (Riskesdas) Tahun 2013. Badan Penelitian dan Pengembangan Kesehatan Kementerian Kesehatan RI: Jakarta.

Sugiyono. (2010). Statistik Untuk Penelitian. CV Alvabeta: Bandung 